\title{
PERFORMANCE AND FEASIBILITY STUDY OF A ROOFTOP PV SYSTEM ON A TYPICAL COMMERCIAL BUILDING SPACE
}

\author{
Ahnaf Tahmid Nahian, Md.Tahmid Farhan Himel, Kaiser Habib \\ Institute of Energy, University of Dhaka, Bangladesh \\ Minhazur Rahman, Sharmin Khatun \\ Department of EEE, \\ American International University-Bangladesh
}

\begin{abstract}
In the present scenario, the rapid increase of fuel cost and utility price in Bangladesh is providing hindrance for the growth of its economy. Energy demand is very sensitive for the activities of day to day life. However, the vast availability of rooftop makes our living and working place a lucrative candidate for solar photovoltaic adoption. This research identifies various aspects of solar photovoltaic adoption in commercial spaces where important decision regarding the development of economy take place by considering economic and technical viability through this feasibility study. This technical study suggest that the implementation of solar photovoltaic will remedy the suffering of working people during the time of load shedding. The aim of this paper is to achieve the optimal export rate in different conditions such as incentives, grants, and interest rate. Proper incentives and reduction of bank interest can make the renewable energy electricity generation adoption in commercial building space competitive with traditional power generation. The proposed project life is about 20 years and the payback period is only 7.9 years with positive NPV and higher IRR.
\end{abstract}

Keywords-Solar PV, Electricity, Net metering, NPV, IRR, Payback period

\section{INTRODUCTION}

The most apposite one between many forms of energy, electricity is the dynamic force after all types of human activities, developments and researches in other areas of technologies. Briefly, it is the electricity that gives birth to other technologies. In a typical developing country each $1 \%$ growth of GDP leads to a rise of $1.4 \%$ demand of electricity. Extra electricity consumption is prerequisite to make higher growth in GDP. [1] In 2017, worldwide total electricity generation was $25551.3 \mathrm{TWh}$ out of which $883 \mathrm{TWh}$ was generated from oil, 5915.3 TWh was generated from natural gas, 9723.4 TWh was generated from coal, 2635.6 TWh was generated from nuclear energy, 4059.9 TWh was generated from hydroelectricity and 2151.5 TWh was generated from renewable energy. [2] According to Bangladesh Power development Board, the installed power generation capacity is about $18454 \mathrm{MW}$, derated power generation capacity is 17911 MW out of which $444 \mathrm{MW}$ is generated by coal fired power plants, 9406 MW is generated by gas with $39.97 \%$ plant efficiency, $4490 \mathrm{MW}$ is generated by HFO with $39.89 \%$ plant efficiency, $2181 \mathrm{MW}$ is generated by HSD with $31.69 \%$ of plant efficiency, $230 \mathrm{MW}$ is generated by hydro, and 1160 MW is imported. [3, 4] However of this, Bangladesh quiet strives from foremost scarcity of electricity generation to achieve the daily demand and the peak demand would be approximately 17,304 MW in FY2020 and 25,199 MW in 2025 [5]. According to SREDA, renewable energy adds only $3.06 \%$ in entire energy mix in the year of 2018. [6] In Bangladesh Solar, biomass \& wind are the extended contestant amongst the reachable renewable energy resources. Hypothetically, Bangladesh gets 69,751 TWh energy each year which is 3000 times higher than the conventional electricity generation [7]. In Bangladesh each year, solar radiation has an usual power density of $100-300 \mathrm{~W} / \mathrm{m}^{2}$ which can produce $100 \mathrm{MW}$ electricity with an area of $3-10 \mathrm{~km}^{2}$ with a panel of $10 \%$ efficiency [8]. In a year with $6.8 \%(10,000$ $\mathrm{km}^{2}$ ) of the land of Bangladesh, per capita $3000 \mathrm{kWh}$ electricity mandate can be achieved [9]. The government of Bangladesh acmes the prerequisite of installing rooftop solar PV system due to the shortage of land. It has been found that $1000 \mathrm{MW}$ of solar PV electricity with $75 \mathrm{~W}$ capacity of the solar module can be produced by the total reachable sunny rooftops area in Dhaka city which is $10.554 \mathrm{~km}^{2}$. [10] In Bangladesh only $1.7 \%$ appropriate land area is used for producing electricity from solar PV as the nearby existence of grid connection [11]. It is found that solar PV operated in a grid-connected mode with $10 \%$ efficiency of solar PV system and $200 \mathrm{~W} / \mathrm{m}^{2}$ yearly usual value of solar radiation can produce near 50,174 MW of grid electricity in Bangladesh. [12] 


\section{International Journal of Engineering Applied Sciences and Technology, 2019 \\ Vol. 4, Issue 6, ISSN No. 2455-2143, Pages 11-19 \\ Published Online October 2019 in IJEAST (http://www.ijeast.com)}

\section{Methodology}

The location of the project is a commercial space namely, Lanka Bangla Finance Ltd. Which is situated in Faridpur, Bangladesh. The Geological coordinates of the area is $23.598^{\circ}$ $\mathrm{N}$ (latitude) and $89.8306^{\circ} \mathrm{E}$ (longitude). The area is a two storied commercial building with a rooftop of approximately 2300 sq. feet, with an available area of 1200 aq. Feet in south. The objective of this research is to establish a rooftop PV system on top of the building so that it can supply electricity alongside with the grid to the connected loads in times of black out. To serve this purpose the copy of billing for different months of 2018 and 2019 are collected. The site considered for this project, is a part of urban areas with an existence of grid electricity though the supply is not continuous resulting a number of load shading. Analysis of load profile and load factor was done to proper sizing of PV system. After that, the feasibility analysis and optimization of the system has been done via RET Screen software.

\section{RoOftop PV DeSIGN ANALYSIS}

Rooftop PV system commonly refers to the photovoltaic system having electricity-generation units mounted on the rooftop of a residential or commercial building or structure. The system is more compact compared to ground mounted photovoltaic power stations. The capacity of the system could sometime rise up to megawatt range. Various impacts including seasonal variation, time, latitude, roof slope, roof aspect, shading analysis and vegetation affects the installation process and output of the system.

\section{A. Load Profile}

The building is mainly an office area having diversified load. Depending on the nature of work, miscellaneous loads are operated. The system was designed in such a way that it can cover maximum load of the area. Load profile of the system is shown in Table 1.

The annual electricity consumption of the system are given below as tabular form. It should be noted that entire electricity of the system are supplied by grid utility of local area. Electricity consumption of Load for the year 2019 (Up to June) is shown in Table 2.

Electricity consumption of load for the year of 2018 are presented below as a tabular form in Table 3

\section{B. Load Factor}

Load factor is a crucial part for every existing power system. Demand of energy can be diminished by improving the load factor of the system. By increasing the value of load factor average unit cost (both demand and energy) of the kWh can be deduced. Improving the value of load factor can lead to the substantial savings. High load factor indicates an efficient system. The value of load factor can be calculated as the ratio of actual energy consumption $(\mathrm{kWh})$ and the maximum power recorded (demand) for that period of time. Thus the equation of the load factor can be determined as

\section{Load Factor $=\frac{\text { Total } k W h \text { for billing period } * 100}{\text { Maximum Demand } * \text { Number of Days } * 24}$}

Value of load factor can be derived from the load profile. The output is always less than one because the maximum demand is always higher than the average load. High value of load factor implies constant power utilization, where the lower value of load factor implies occasional high demand of power. According to electrical rating system, power system having higher value of load factor are charged less overall per kWh. This is called load balancing mechanism. Load factor for the different months of year 2018 is shown in Table 4. Load factor for the different months of year 2019 is shown in Table 5.

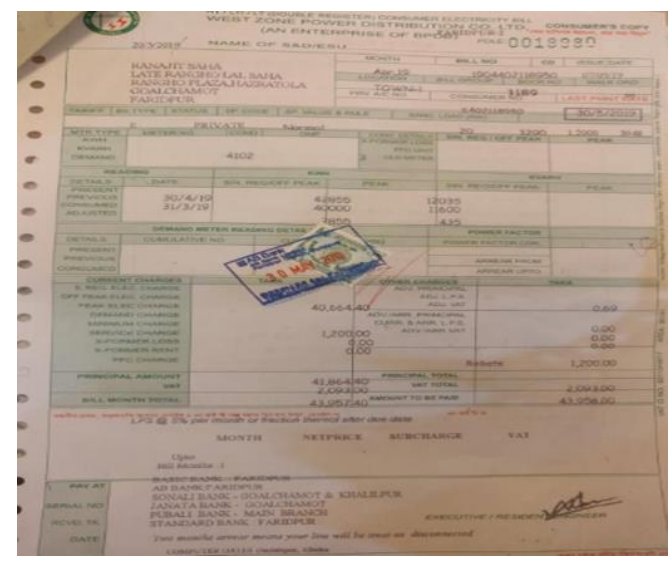

Fig 1 Utility grid bill for the month of April 2019

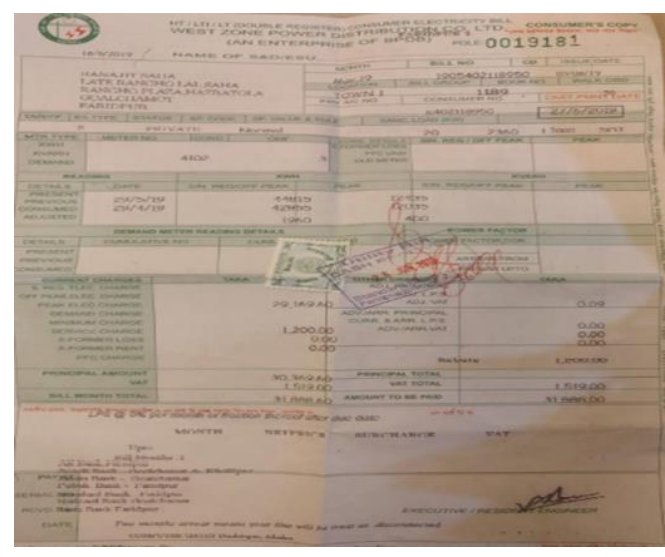

Fig 2 Utility grid bill for the month of May 2019 


\section{International Journal of Engineering Applied Sciences and Technology, 2019 \\ Vol. 4, Issue 6, ISSN No. 2455-2143, Pages 11-19 \\ Published Online October 2019 in IJEAST (http://www.ijeast.com)}

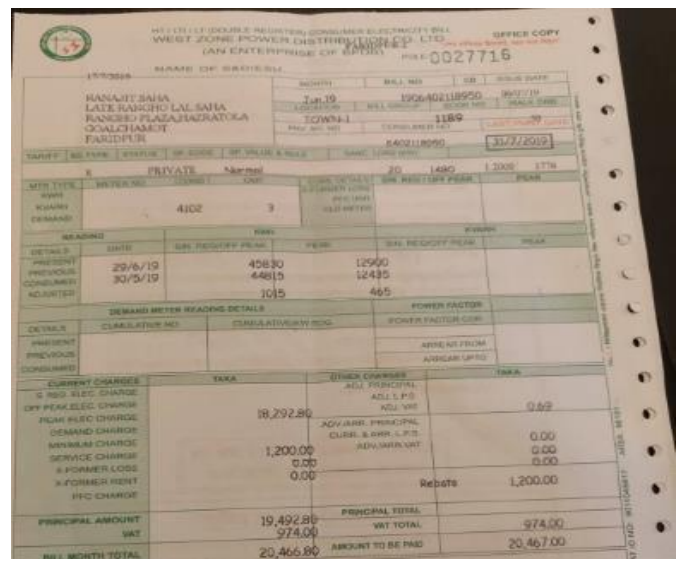

Fig 3 Utility grid bill for the month of June 2019

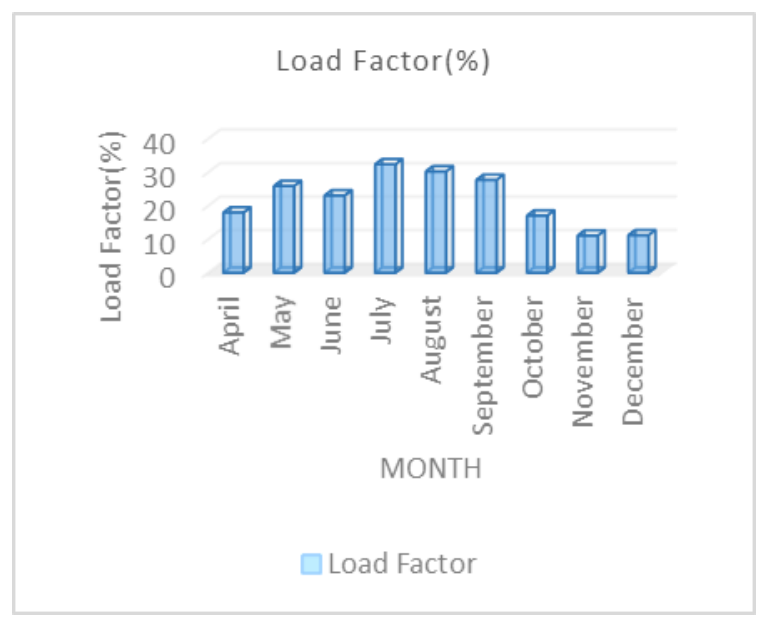

Fig 4 Load factor for the different months of year 2018

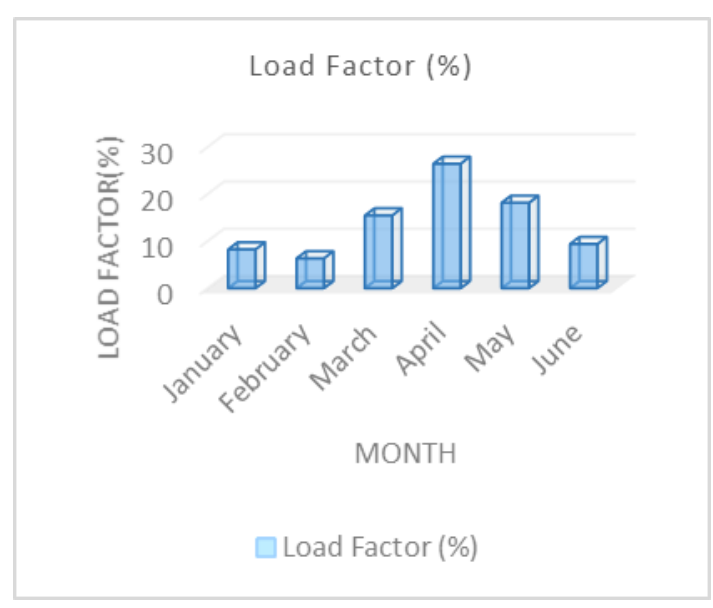

Fig 5 Load factor for the different months of year 2019

\section{Design of a Typical Off grid Rooftop PV system}

Design of a rooftop PV system needs considerations on many aspects. System has to be proper sized otherwise there will be unnecessary production of electricity which will cause the system damage and will increase the electricity generation cost.

\section{Array sizing:}

Due to the size of the rooftop, maximum PV array that could be installed is $10 \mathrm{kWp}$. The panel capacity is chosen as 250 Wp.

No of Panels $=10000 / 250=40$

No of Array= 2, (5 kWp each)

No of Module in series Ns $=20$

No of Module in parallel $=2$

Selection of a Grid-Tied Inverter:

Number of inverters required for the system $=2$ (each rated $5 \mathrm{~kW}, 48 \mathrm{v}$ )

\section{Battery Sizing:}

The battery capacity required at $\mathrm{C}(\mathrm{Ah})$ should be calculated using the following formula

$C(A h)=\frac{P L(A h) * \text { Backup time }}{D O D * \text { Efficiency of the battery system } * \text { Inverter } E \text { f ficiency }}$

Total no. of battery required $=20 * 1=20$

\section{Design and Analysis of Standalone PV System by Useful Parameters}

A small office with a boundary area of 2300 sq. feet has been considered for the project. The two storied building has two working space. The connected load of the space is $15 \mathrm{~kW}$. Depending on the value of utility's consumption this area needs about $250 \mathrm{Wp} \mathrm{PV}$ panel. The proposed system is off grid and will act as an independent solar home system. Rooftop of the building is chosen as the area for the system setup. The block diagram of proposed PV system are presented below. In this system two $250 \mathrm{Wp} \mathrm{PV}$ array are chosen as the main power source of the system with a panel capacity of $250 \mathrm{Wp}$. The panels directly lead to the DC distribution box via MPPT charge controller (120A). From their connections are given to the battery bank so that they can store charges that can be used in the time of need. Other connections are directed to the inverters (48 V, $800 \mathrm{VA})$, so that the dc power produced from the PV can be converted into $\mathrm{AC}$ power. From inverter the system connections were given to AC distribution box. Two types of protecting mechanism MCB \& MCCB are used in this process. After that the output $\mathrm{PV}$ power is lead to the AC plug in port via metering units.

The analysis is mainly done for a typical rooftop PV system wish to be founded on the surface of rooftop. For the design and simulation purpose electricity consumption for the month of May 2019 has chosen as it yield higher load factor and a feasible cost effective load solution. According to the collected billing data, the month (May) yield a very high load factor, this system is also appropriate for the months with lower value of load factor. 
International Journal of Engineering Applied Sciences and Technology, 2019

Vol. 4, Issue 6, ISSN No. 2455-2143, Pages 11-19

Published Online October 2019 in IJEAST (http://www.ijeast.com)

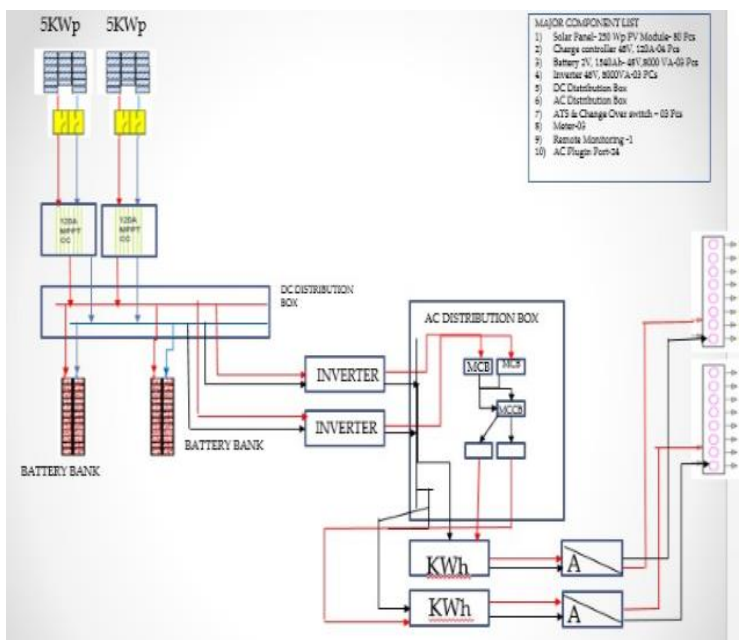

Fig 6 Block diagram of the PV system (off grid)

Table 1 Load profile of the system

\begin{tabular}{ccccc}
\hline Load & $\begin{array}{c}\text { Hours of use per } \\
\text { day(hr) }\end{array}$ & $\begin{array}{c}\text { Watt rating (W) } \\
\text { (Base case Load) }\end{array}$ & Days of use per week & Load type(AC) \\
\hline LED & 6 & 150 & 5 & Positive \\
Photocopy & 3.50 & 1300 & 5 & Positive \\
Oven & 2 & 2400 & 5 & Positive \\
Fridge & 24 & 1000 & 7 & Zero \\
Coffee maker & 1.50 & 800 & 5 & Positive \\
AC & 5 & 8000 & 5 & Positive \\
CC camera & 24 & 30 & 5 & Zero \\
Phone charger & 5 & 100 & 5 & Positive \\
Printer and scanne & 2 & 50 & 5 & Positive \\
Laptop & 4 & 500 & 5 & Positive \\
Table fan & 3 & 10 & 5 & Positive \\
Phone charger & 2 & Total load=15kW & Total Energy=63.25 \\
\hline Total & & & kWh \\
\hline
\end{tabular}

Table 2 Electricity consumption of Load for the year 2019 (Up to June)

\begin{tabular}{ccc}
\hline Months & Electricity Consumption(kWh) \\
\hline January & 890 \\
February & 685 \\
March & 1670 \\
April & 2855 \\
May & 1960 \\
June & 1015 \\
\hline
\end{tabular}

Table 3 Electricity consumption of Load for the year 2018 (April to December)

\begin{tabular}{ccc}
\hline Months & Electricity Consumption (kWh) \\
\hline April & 1945 \\
May & 2800 \\
June & 2500 \\
July & 3500 & 3270 \\
August & 3000 \\
September & 1845 \\
October & 1200 \\
November & 1210 \\
\hline
\end{tabular}




\section{International Journal of Engineering Applied Sciences and Technology, 2019 \\ Vol. 4, Issue 6, ISSN No. 2455-2143, Pages 11-19 \\ Published Online October 2019 in IJEAST (http://www.ijeast.com)}

Table 4 Load factor for the different months of year 2018

\begin{tabular}{cc}
\hline Months & $\begin{array}{c}\text { Load Factor } \\
(\boldsymbol{\%})\end{array}$ \\
\hline April & 18 \\
May & 25.92 \\
June & 23.1 \\
July & 32.40 \\
August & 30.27 \\
September & 27.77 \\
October & 17.08 \\
November & 11.11 \\
\hline
\end{tabular}

Table 5 Load factor for the different months of year 2019

\begin{tabular}{c}
\hline Months \\
January \\
February \\
March \\
April \\
May \\
June \\
\hline FEASIBILITY \& PERFORMANCE STUDY OF A PV SYSTEM \\
BY RET SCREEN SOFTWARE
\end{tabular}

According to load profile and considering two days of autonomy and other conditions simulation was run in RET Screen and found that the number of module required to sustain this project was $10 \mathrm{kWp}$ with $18000 \mathrm{Ah}, 12 \mathrm{~V}$ battery. The electricity generation were used as financial indicator of our system. These data are presented below in tabular form. Electricity generation for different solar radiation is shown in Table 6.

\section{A. Financial Analysis by RET Screen}

To evaluate a project or investment, it is important to calculate the NPV, IRR, Payback period, Year to positive cash flow and PI index for the project. The parameter is very sensitive to PV cost, subsidy, discount rate and energy price rate. Financial viability for off grid and grid tied system is shown in Table 7. Financial parameter for off grid and grid tied system is shown in Table 8. Initial cost (BDT) for off grid system and grid tied system is shown in Table 9. Balance of system \& miscellaneous cost (BDT) for off grid system is shown in Table 10. Annual cost \& Debt Payment is shown in Table 11.

\section{B. Cumulative Cash Flow Graph}

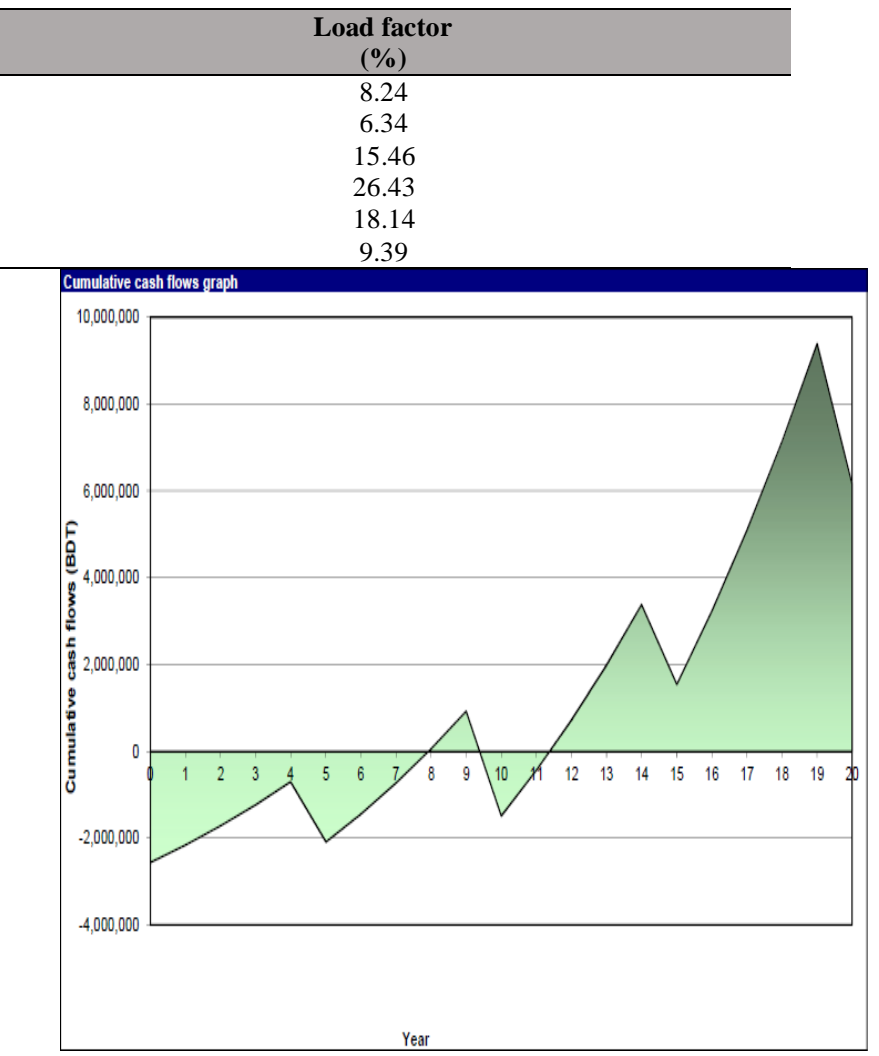

Fig 7 Cumulative cash flow diagram of a 10kW off-grid (battery backup) system

Above figure explains the cash flow of the entire project. According to diagram it takes more than 8 years for the project to reach the break even. Up to eight years cash flow is negative which indicates that the project won't be feasible up to this period. After 19 years the cash flow will reach up to its peak value. Maintenance and components replacement costs will increase the overall system cost which will impact on benefit to cost ration of the project. But considering overall scenario of the project it is found that the project is feasible and implementation of this project will help to offset the consequences of random blackout of this particular zone. 
International Journal of Engineering Applied Sciences and Technology, 2019

Vol. 4, Issue 6, ISSN No. 2455-2143, Pages 11-19

Published Online October 2019 in IJEAST (http://www.ijeast.com)

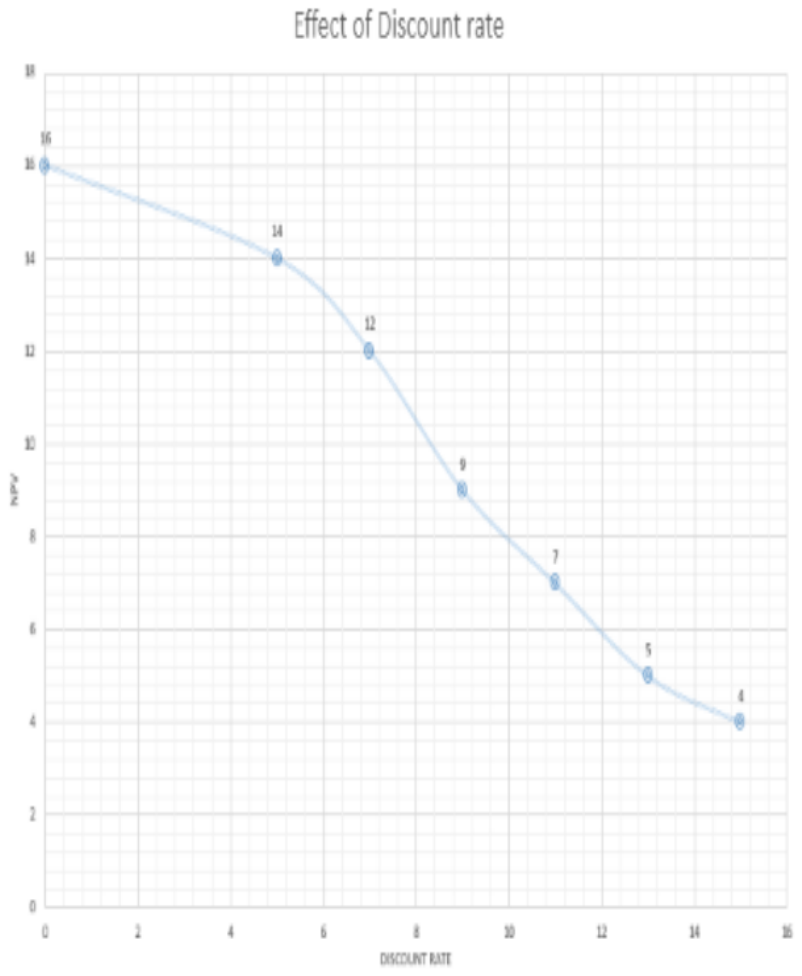

Fig 8 Effect of discount rate

The effect of discount rate on NPV is shown below. The project is feasible but NPV is declining with the increase of discount rate.

Table 6 Electricity generation for different solar radiation

\begin{tabular}{cccc}
\hline Month & $\begin{array}{c}\text { Daily solar radiation- } \\
\text { horizontal } \\
\mathbf{k W h} / \mathbf{m}^{\mathbf{2} / \mathbf{d}}\end{array}$ & $\begin{array}{c}\text { Daily solar radiation- } \\
\text { Tilted } \\
\mathbf{k W h} / \mathbf{m}^{\mathbf{2}} \mathbf{d}\end{array}$ & $\begin{array}{c}\text { Electricity Delivered to } \\
\text { Load } \\
\mathbf{M W h}\end{array}$ \\
\hline January & 4.36 & 5.56 & 1.18 \\
February & 4.92 & 5.78 & 1.07 \\
March & 5.59 & 6.00 & 1.21 \\
April & 5.76 & 5.69 & 1.12 \\
May & 5.30 & 4.97 & 1.02 \\
June & 4.53 & 4.19 & 0.84 \\
July & 4.23 & 3.96 & 0.82 \\
August & 4.29 & 4.15 & 0.85 \\
September & 4.02 & 4.10 & 0.82 \\
October & 4.32 & 4.82 & 0.99 \\
November & 4.28 & 5.30 & 1.06 \\
December & 4.21 & 5.52 & 1.15 \\
Annual & $\mathbf{4 . 6 5}$ & $\mathbf{5 . 0 0}$ & $\mathbf{1 2 . 0 9}$ \\
\hline
\end{tabular}

Table 7 Financial viability for off grid and grid tied system

\begin{tabular}{|c|c|c|c|c|c|c|c|c|c|c|c|}
\hline & $\begin{array}{c}\text { Pre-tax } \\
\text { IRR- } \\
\text { equity } \\
(\%)\end{array}$ & $\begin{array}{c}\text { Pre-tax } \\
\text { IRR- } \\
\text { assets } \\
(\%)\end{array}$ & $\begin{array}{l}\text { After- } \\
\text { tax } \\
\text { IRR- } \\
\text { equity } \\
(\%)\end{array}$ & $\begin{array}{l}\text { After- } \\
\text { tax } \\
\text { IRR- } \\
\text { assets } \\
(\%)\end{array}$ & $\begin{array}{c}\text { Simple } \\
\text { Payback } \\
\text { (yr) }\end{array}$ & $\begin{array}{c}\text { Equity } \\
\text { Payback } \\
\text { (yr) }\end{array}$ & $\begin{array}{c}\text { Net } \\
\text { present } \\
\text { value } \\
\text { (NPV) } \\
\text { (BDT) }\end{array}$ & $\begin{array}{c}\text { Annual } \\
\text { life cycle } \\
\text { savings } \\
\text { (BDT/yr) }\end{array}$ & $\begin{array}{l}\text { Benefit- } \\
\text { cost } \\
\text { ratio }\end{array}$ & $\begin{array}{c}\text { GHG } \\
\text { Reduction } \\
\text { Cost } \\
\text { (BDT/tCO2) }\end{array}$ & $\begin{array}{c}\text { Energy } \\
\text { Production } \\
\text { cost } \\
\text { (BDT/MWh) }\end{array}$ \\
\hline Off-grid & 12.6 & 12.6 & 12.6 & 12.6 & 7.0 & 7.9 & $8,66,963$ & 94,973 & 13.4 & 14,354 & \\
\hline
\end{tabular}


International Journal of Engineering Applied Sciences and Technology, 2019

Vol. 4, Issue 6, ISSN No. 2455-2143, Pages 11-19

Published Online October 2019 in IJEAST (http://www.ijeast.com)

\begin{tabular}{|c|c|c|c|c|c|c|c|c|c|c|c|}
\hline $\begin{array}{l}\text { (battery } \\
\text { backup } \\
\text { system) }\end{array}$ & & & & & & & & & & & \\
\hline $\begin{array}{c}\text { Grid- } \\
\text { tied } \\
\text { system } \\
\text { With net } \\
\text { metering }\end{array}$ & negative & negative & negative & negative & 13.8 & $>$ project & $\begin{array}{c}- \\
959,398\end{array}$ & $-105,099$ & 0.07 & 12,458 & $12,316.80$ \\
\hline
\end{tabular}

Table 8 Financial parameter for off grid and grid tied system

\begin{tabular}{ccc}
\hline Parameter & Off grid system & Grid tied system \\
\hline Fuel cost escalation rate (\%) & 10 & 10 \\
Inflation rate (\%) & 5.5 & 5.5 \\
Discount (\%) & 9 & 9 \\
Project life (yr) & 20 & 20 \\
\hline
\end{tabular}

Table 9 Initial cost (BDT) for off grid system and grid tied system

\begin{tabular}{cccc}
\hline Parameter & Percentage (\%) & $\begin{array}{c}\text { Initial cost (BDT) for off } \\
\text { grid system }\end{array}$ & $\begin{array}{c}\text { Initial cost (BDT) for grid- } \\
\text { tied system }\end{array}$ \\
\hline Feasibility study & 0.4 & 10,000 & 10,000 \\
Development & 0.4 & 10,000 & 10,000 \\
Engineering & 0.4 & 10,000 & 10,000 \\
Power system & 22.1 & $5,65,000$ & $5,50,000$ \\
Balance of system \& & 76.7 & $19,62,000$ & $4,50,000$ \\
miscellaneous & & & $\mathbf{1 0 , 3 0 , 0 0 0}$ \\
Total & $\mathbf{1 0 0}$ & $\mathbf{2 5 , 5 7 , 0 0 0}$ & \\
\hline
\end{tabular}

Table 10 Balance of system \& miscellaneous cost (BDT) for off grid system

\begin{tabular}{ccc}
\hline Specific project cost & Power Rating & Price (BDT) \\
\hline Inverter & $15 \mathrm{~kW}$ & $4,50,000$ \\
Battery & $216 \mathrm{kWh}$ & $15,12,000$ \\
Subtotal cost & & $19,62,000$ \\
Total cost(including contingencies and & & $20,07,000$ \\
interest during construction) & & \\
\hline
\end{tabular}

Table 11 Annual cost \& Debt Payment

\begin{tabular}{ccc}
\hline Annual cost \& Debt Payment & Price(BDT) for off grid system & Price(BDT) for grid tied system \\
\hline Operation \& Maintenance & 10,000 & 10,000 \\
Fuel cost-proposed Case & $1,53,899$ & 0 \\
Total annual cost(BDT) & $1,63,899$ & 10,000 \\
Periodic cost(credits) & $15,12,000$ & $4,50,000$ \\
Fuel cost(base case) & $5,26,648$ & 0 \\
Electricity export income(BDT) & & 84,797 \\
Total annual savings \& income(BDT) & $\mathbf{5 , 2 6 , 6 4 8}$ & $\mathbf{8 4 , 7 9 7}$ \\
\hline
\end{tabular}




\section{Cumulative Cash Flow Graph}

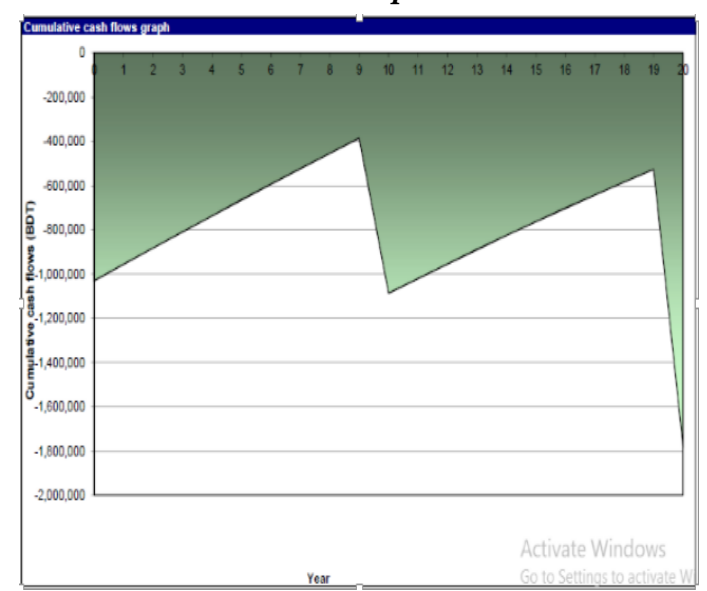

Fig 9 Cumulative cash flow diagram of grid-tied net metering system

Above figure explains about the cumulative cash flow of grid tied net metering system, where the PV generator is supposed to feed only the grid according to the net metering policy. According to diagram it is seen that the project is not be feasible (even after 20 year). NPV of the project is negative and benefit to cost ratio is almost zero which also indicates towards the negative feasibility of the entire project. It's because according to policy of net metering system in Bangladesh electricity export rate is only 5.5 taka which is quite less than the electricity production cost by PV generator as they require annual maintenance and operating cost. Besides the roof area for the installation project is not sufficient for large scale production of electricity. That's why the idea of on grid system with net metering mechanism is not feasible for this project.

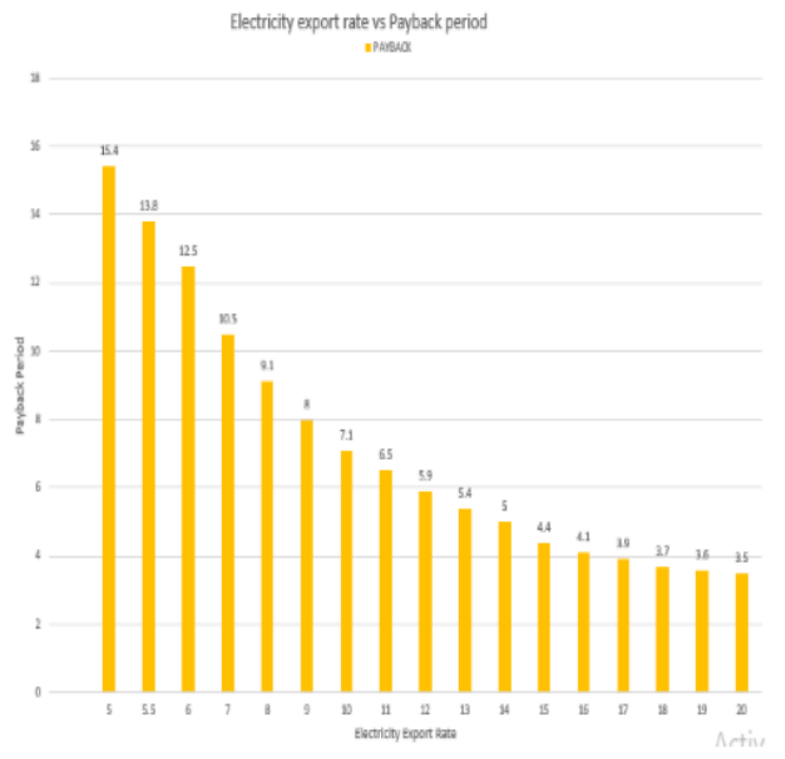

Fig 10 Graphical representation of electricity export rate with payback period
According to the above figure it is seen that by increasing the value of electricity export rate payback period decreases from the system. Higher value of electricity export rate corresponds to lower payback period in case of grid tied net metering system. If the electricity export rate is $20 \mathrm{BDT} / \mathrm{kWh}$ then the payback period will be low as 3.5 years which is impractical due to current utility grid rate.

\section{CONCLUSION}

Access of electricity has a sustainable impact on economic development, growth of productivity and local employment. To raise an economy into an upward spiral of continuous prosperity, some basic criterion must be afforded. Providing sufficient electricity from a reliable power source is one of the prerequisite for an important catalyst for sustainable development. The goal of this research was to perform a feasible study on setting an off grid rooftop PV system on the roof space of a commercial building. To design this optimal power solution, a detail study was done about the location, resource evaluation and load analysis on apparel division of the particular space (Lanka Bangla Finance Ltd, Faridpur Branch). After considering the load requirements a system based on renewable resources to power the load with an assurance of quality, warranty, cost of servicing, spare parts availability and maintenance to ensure uninterrupted supply of electricity was proposed.

\section{REFERENCES}

[1] Asit Mohanty \& Devtosh Chaturvedi. Relationship between Electricity Energy Consumption and GDP: Evidence from India. International Journal of Economics and Finance; Vol. 7, No. 2; 2015. doi:10.5539/ijef.v7n2p186

[2] BP Statistical Review of World Energy, June-2018

[3]Bangladesh power Development Board

http://www.bpdb.gov.bd/bpdb_new/index.php/site/owner_wis e_daily_generation 2019

[4] Dr Khondaker Golam Moazzem, Mohammad Ali. The Power and Energy Sector of Bangladesh: Challenges of Moving beyond the Transition Stage. Paper is presented in a national dialogue on "Power and Energy Sector: Immediate Issues and Challenges" organized by the Centre for Policy Dialogue (CPD) held on 10 March, 2019.)

[5] Md.Tahmid Farhan Himel and Ahnaf Tahmid Nahian, "Integrated Energy Management of Residential Halls at University of Dhaka by Using Energy Efficient Appliances and Solar PV System", International Journal of Engineering and Management Research vol-9, no 1, pp. 87-100 http://doi.org/10.31033/ijemr.9.1.7

[6] Sustainable and Renewable Energy Development Authority

(http://www.sreda.gov.bd/index.php/site/re_present_status) 2019 
[7] M. S. H. Lipu, M. S. Uddin, and M. A. R. Miah, "A Feasibility Study of Solar-Wind-Diesel Hybrid System in Rural and Remote Areas of Bangladesh," Int J Renew Energy Res, vol. 3, no. 4, pp. 892-900,

[8] B. Van der Zwaan and A. Rabl, "Prospects for PV: a learning curve analysis," Sol Energy, vol. 74, no. 1, pp. 19-31, 2003.

[9] S. Islam and A.-U. Huda, "Technical note Proper utilization of solar energy in Bangladesh: effect on the environment, food supply and the standard of living," Renew Energy, vol. 17, no. 2, pp. 255-263, Jun. 1999.

[10] M. H. Kabir, W. Endlicher, and J. Jägermeyr, "Calculation of bright roof-tops for solar PV applications in Dhaka Megacity, Bangladesh,” Renew Energy, vol. 35, no. 8, pp. 1760-1764, 2010.

[11] B. Sørensen, "GIS management of solar resource data," Sol Energy Mater Sol Cells, vol. 67, no. 1, pp. 503-509, 2001.

[12] M. A. H. Mondal and M. Denich, "Assessment of renewable energy resources potential for electricity generation in Bangladesh," Renew Sustain Energy Rev, vol. 14, no. 8, pp. 2401-2413, 2010. 